\title{
Islamic Social Principles for a Friendly and Pleasant Environment: A lesson from Kitab Al-Jidar
}

\author{
Sharifah Fadylawaty Syed Abdullah, Mohd Dani Muhamad, Amal Hayati Ishak, Ezani Yaakob \\ Academy of Contemporary Islamic Studies (ACIS), \\ Universiti Teknologi MARA (UiTM),Shah Alam, 40450 Shah Alam, Selangor, Malaysia \\ fadylawaty4935@uitm.edu.my, mdani393@uitm.edu.my, amalhayati@uitm.edu.my, ezani@uitm.edu.my \\ Tel of 1st Author: +60199320469
}

\begin{abstract}
Low social ties among society occurred due to the lack of social interaction and civic engagement. The purpose of this paper is to explore the manifestation of Islamic social principles in Kitab Al-Jidar. This qualitative method accomplished the content analysis process. This study found that five (5) social principles in Kitab Al-Jidar has potential to maintain healthy social relations. It is hoped that this paper would infuse awareness among modern society to play their role as a community member in creating a friendly and pleasant environment based on Islamic social principles.
\end{abstract}

Keywords: traditional Islamic ; built environment ; Islamic principles ; social environment

eISSN: 2398-4287 @ 2021. The Authors. Published for AMER ABRA cE-Bs by e-International Publishing House, Ltd., UK. This is an open access article under the CC BYNC-ND license (http://creativecommons.org/licenses/by-nc-nd/4.0/). Peer-review under responsibility of AMER (Association of Malaysian Environment-Behaviour Researchers), ABRA (Association of Behavioural Researchers on Asians) and cE-Bs (Centre for Environment-Behaviour Studies), Faculty of Architecture, Planning \& Surveying, Universiti Teknologi MARA, Malaysia.

DOI: https://doi.org/10.21834/ebpj.v6iSl5.2923

\subsection{Introduction}

Modern society is marked by a lack of social interaction and civic engagement with a larger society (Osman, Rabe, \& Bachok, 2011; Nahar, Sangi, Rosli, \& Abdullah, 2018). This problem may be influenced by social, cultural, technological and political factors (Salih \& Ismail, 2018). In a similar vein, contemporary scholars have laid down several principles to regulate the social interaction and social responsibility among residences in contemporary Islamic built environment (Mortada, 2003). Muslims are expected to practice ethical and social values such as hospitality, trust, justice and helpfulness (Shari \& Murayama, 2013; Mohammed \& Mahmoud, 2013; Othman, Aird \& Buys, 2015). Islam strongly encourages kindness and hospitality to its neighbours, as stated in Surah al-Nisa: 36 . The act of kindness is valued by the Creator and can sustain the peace and harmony of the universe (Abu-Ghazzeh, 1994). Numerous literatures emphasize the importance of respect to the rights of neighbours to maintain a good relationship in the Islamic built environment (Mohammed \& Mahmoud, 2013; Zeenat Begam Yusof, 2015). Most of the previous studies have indicated that there should be an integration between the physical, social and spiritual elements in the neighbourhood's development based on the Islamic perspective. Therefore, this article aims to explore the manifestation of social principles from Kitab Al-Jidar in empowering a friendly and pleasant traditional built environment.

\subsection{Literature Review}

Based on the previous resources, the researcher found that there are five (5) guiding principles for improving the social environment as followings:

eISSN: 2398-4287 @ 2021. The Authors. Published for AMER ABRA cE-Bs by e-International Publishing House, Ltd., UK. This is an open access article under the CC BYNC-ND license (http://creativecommons.org/licenses/by-nc-nd/4.0/). Peer-review under responsibility of AMER (Association of Malaysian Environment-Behaviou Researchers), ABRA (Association of Behavioural Researchers on Asians) and cE-Bs (Centre for Environment-Behaviour Studies), Faculty of Architecture, Planning \& Surveying, Universiti Teknologi MARA, Malaysia.

DOI: https://doi.org/10.21834/ebpj.v6iSl5.2923 


\subsection{Right to use open spaces}

Traditionally, the open space or courtyard of a house in the reserve road is known as fina (Hakim, 1986; Al-Hathloul, 1996; Mortada, 2003; Nooraddin, 2016). There are two types of fina: open public spaces and open private spaces (Al-Hathloul, 1996 \& Nooraddin, 2016). The former usually refers to large areas or thoroughfares, while the latter are lanes or cul-de-sac. Besim (1986) illustrated fina, as presented in Figure 1.

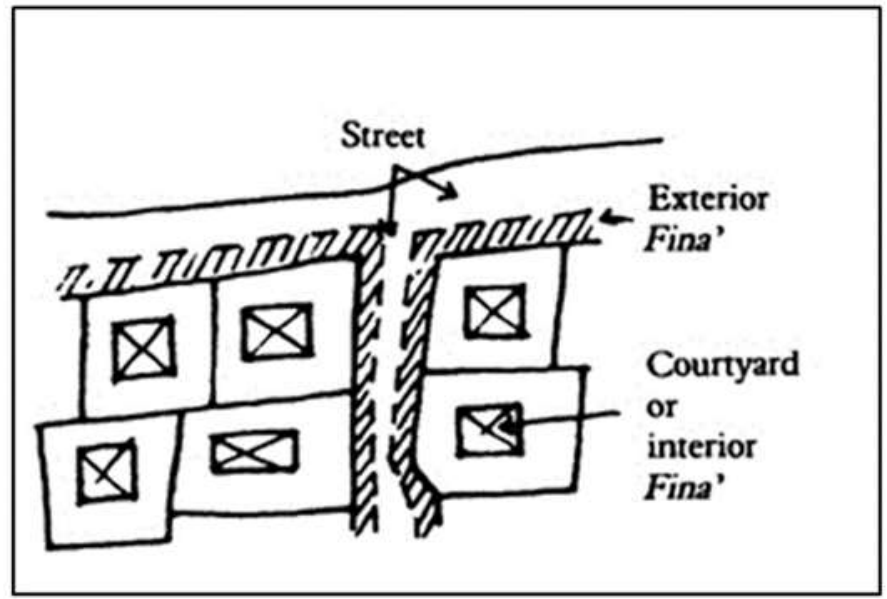

Fig 1: Fina

( Source: Besim Selim Hakim (1986))

There are different opinions given by Muslim scholars about the ownership of fina. According to Imam Syafi'e, fina is owned by the abutters, i.e. jointly owned by the dwellers whose buildings have been affected or annexed (Akbar, 1988). In comparison, Umar viewed that the fina belongs to the owner of the house (in front of the lawn and the backyard). At the same time, Abu Hanifah divided fina into two parts: external or public fina, internal fina or private fina. Public fina belonged to all Muslims, while private fina belonged to the abutters only (Akbar, 1988; Hossam Mahdy, 2017).

While concerning the right to use fina, only abutters are permitted to use fina for daily purposes (Hakim, 1986; Al-Hathloul, 1996; Mortada, 2003; Hossam Mahdy, 2017). They may use the fina for loading, storing, temporary parking of individual animals and socializing with other residents (Hakim, 1986; Al-Hathloul, 1996; Mortada, 2003; Hossam Mahdy, 2017). However, authorization for the use of the fina is subject to few conditions including; a) there should be no harm to the public, in particular to passers-by, b) no damage to the circulation system, and c) no hindrance to others in benefiting the fina (Akbar, 1988; Al-Hathloul, 1996; Hossam Mahdy, 2017).

\subsection{Right of property}

Islam respects the right of people to their possessions. Consequently, the owner is fully entitled to renovate or restore his property if no harm has been caused to others (Hakim, 1986). In the case of adjoining party walls, Muslim jurists accept that the owner can reasonably manipulate his property without the permission of his neighbour (Azila Sarkawi, 2008; Bagaeen, 2010). However, the consent from his neighbours is required if the action is likely to affect his neighbour (Al-Hathloul, 1996).

\subsection{Right of privacy}

Islam promotes mutual respect for the privacy of individuals. For example, one must ask for permission before entering the dwelling of others to respect their privacy. Besides, Islam also teaches young people to respect the dignity of adults in verse 58: Surah al-Nur by specifying the appropriate timeframes that must be kept preserving privacy.In a similar vein, Hakim (1986) also emphasizes the preservation of privacy through the behaviour of announcing one's presence to the occupants of a dwelling. Islam has stressed that it is prohibited to spy on the houses of others as consorted in the following verse 12 : Surah Al-Hujurat.Hakim (1986), Mortada (2003), Mohamad Mahdi et al. (2011) and Daneshpour (2011) agreed that the buildings should be built to promote respect for the privacy of residents from a direct view of outsiders. Such designs also allow people to cover 'awrah,' which is mandatory for all Muslims (Norisma et al., 2017).

\subsection{Self-built system}

In the traditional Islamic built environment, the community carried out the construction work on their own to produce appropriate facilities as the community-led projects (Bartuska, 2007; Emmanuel, 2016). For this reason, the instrument of waqf is typically implemented to ensure the sustainability of the facilities (Shaikh, 2015). Waqf is an individual commitment to religion (Hakim, 1986; Akbar, 1988:2003 \& Shaikh, 2015). The wagf scheme has been widely applied throughout the Islamic empire and is still a widespread practice in the Muslim world (Raymond, 1984; Shaikh, 2015). During the Ottoman era, many public properties such as mosques, hammams and drinking fountains were built by waqf (Raymond, 1984; Akbar, 1988; Akbar, 1988:2002; Ayyoob \& Akito, 2012). 


\subsection{Responsibility for infrastructure maintenance}

In the traditional neighbourhood, the inhabitants are responsible for the cleanliness and preservation of neighbourhood areas (Hakim, 1986; Akeel Nouri, 2009). In the opinion of Kadi Ar-Rafi, those who were hesitant to retain the infrastructure such as cul-de-sacs should be encouraged to participate. However, Maliki jurists note that no force can be imposed to gain their consent (Hakim 1986). In a case where the approval is granted, the funding is then collected based on the proportionate wealth. The justification for a proportional wealth is that the wealthy typically need more protection from burglary than the less affluent. Therefore, they should allocate more money than the poor (Hakim, 1986).

\subsection{Methodology}

This research uses a qualitative approach where the extensive reading of the main text, Kitab Al-Jidar is conducted, in addition to some other relevant reading materials. The content analysis approach is accomplished to define and extract the principles and manifestation of Islamic social principles discussed. This book is imperative and significant to provide guidelines of the traditional Islamic built environment for contemporary practices.

\subsection{Findings}

\subsection{Brief Background of the Kitab Al-Jidar}

Kitab Al-Jidar is an original masterpiece of Isa ibn Dinar (212 A.H). The background of the author is not as complete as the information about Ibn Al-Rami (author for Kitab Al-'Ilan bi Ahkam Al-Bunyan). This book was missing and untraceable. However, the name of the author and his book repeatedly mentioned by the later authors, e.g. by Isa b. Musa at-Tutili.

Kitab al-Jidar by Isa b. Musa at Tutili (d. 386 A.D.) is an influential book to be referred to as it was an early manuscript discussing the Islamic built environment. There are 51 topics of discussion related to the built environment. Four manuscripts of this book can be found in Tunis, Algeria and Morocco. The outcomes of his writing are critical and meaningful since the discussion are very detailed. The debate in this book cites the views of some Maliki scholars, namely Sahnun, Asbagh ibn Al-Faraj, Mohammad bin Telid, Ibn Majshun and Al-Qasim.

\subsection{Manifestation of Social Principles in Traditional Islamic Built Environment According to the Kitab Al-Jidar}

\subsubsection{Right of use of open spaces}

There are two types of open spaces in Kitab Al-Jidar that are al-fina' and Saha. Fina, as most jurists have pointed out, refers to the area which is adjacent to the door of the building or space that surrounds the household and does typically not reach more than half the width of the street. The fina' can, therefore, be a space belonging to the person who has a door opening into the street. Ibn Habib reports that he heard Motarref and lbn el Majshun say that Malek did not allow finas to be shared in front of the houses along the roads, even though the inhabitants would agree to share them since they use these spaces.

In Kitab Al-Jidar, Omar stipulated that the owners of the adjacent homes have the right to enjoy sitting there, bringing animals to it and putting shops in it. People are permitted to sell small items, but not to enclose them. This judgement is the accurate interpretation of the of Omar and has been explained by some authoritative scholars. Ibn Kenana stated that no tolerance for those who shrink the street by adding plots to their homes or shops. No one has the right to demolish the public space either along with the houses, streets or the markets. It often happens to the city that a person trespasses on the street by shifting a stone from its building or something, but then the authority must remove what stands out unless the projection is so small that no one is disturbed.

\subsubsection{Right of property}

Kitab Al-Jidar recognizes property rights in term of ownership and usage. The property right highlighted in Kitab Al-Jidar includes houses, walls, fina' and Saha (yard). In Islam, the owner of the property enjoys independence and freedoms over his property. The owner has the right to renovate his property but still subject to the Dharar Principle. The right of al-irtifaq, which includes the right to drink water (shirb), the right to irrigate crops, the right to air, the right of passage, the right of al-ta'alli (upper and lower occupants) and the right of precedence also illustrated in Kitab Al-Jidar. None of these rights can be refused and should be appropriately benefited. Kitab Al-Jidar also referred to the right of syufah. In Islamic law, al-syuf'ah affords the co-proprietors of undivided shares in the property the preferential right to purchase the shares of other co-proprietors before the shares can be offered to outsiders.

\subsubsection{Right of privacy}

Islam emphasizes the preservation of privacy as it is closely related to the concept of 'awrah.' The debate in Kitab Al-Jidar reinforces the prohibition of violating the visual privacy of the neighbour. An opening or a hole is considered dangerous if it allows a person to see a neighbour's house when he or she is standing in front of his or her neighbour's door or hole. The mosque tower should also be demolished if it is found to infringe visual privacy.

Among the manifestations of figh explained in the Kitab Al-Jidar, there should be the prevention of visual damage, including an attempt to locate a door that does not directly face a neighbour's door or open a second entrance. While the positioning of the window is determined using a bench or a bed. In the circumstance that the house opening is directly facing the street (public and private), the 
street should be situated very far from the neighbour's home. Otherwise, the street would have to be very wide, so that no one could intervene with the visual privacy of the inhabitants from outside. The required width of the street to prevent the invasion of privacy is seven cubits, based on the hadith of the Prophet SAW. At the same time, it is the responsibility of the individual to make reasonable precaution to counter visual damage. Possible steps to safeguard against visual intrusion include closing or removing the holes, adjusting the location of the door or window, as well as the placement of the screen. Also, the right to privacy implies that residents or neighbours in the area are not impacted by irritating sound transmission. Sources of noise should be eliminated or at least minimize if they irritate and cause inconvenience to others.

\subsubsection{Self-built system}

The provision of necessary facilities in the neighbourhood, such as gates, mosques, kuttab and hammams, is utilizing waqf instruments, either waqf khayri or waqf zhurri (Muhtar, 2015). Waqf khayri or voluntary waqf refers to the eternal charitable organization of public welfare properties and services (Hakim 1986; Muhtar, 2015). While, in Waqf zhurri (waqf descendant), the wealth or other property generally allocated to deserving descendants and heirs at the time of the beneficiary's death (Hakim 1986; (Muhtar 2015).

\subsubsection{Responsibility for infrastructure maintenance}

Kitab Al-Jidar focuses on waste management in multi-storey housing. This book provides the view put forward by Asbagh that the occupants of the ground floor are solely responsible for sweeping and cleaning up the garbage on that floor. They are not supposed to clean up the trash disposed of by the occupants of the ground floor. In the event of a mass of waste in the debris property, Sahnun argued that the owner of the building was responsible for cleaning the garbage since it could harm others.

In another opinion, Sahnun also emphasized civic responsibility, saying that if the garbage and debris of the building endanger the public, it should be managed by the nearest neighbours. In general, the explanation given is that the neighbouring parties are the ones who may produce the waste. As far as domestic waste is concerned, it is the household's responsibility to manage and dispose of it. Any conduct or practice, such as garbage disposal, which is not adequately managed and pollute the atmosphere, water, air or landscape, is considered a sin and strictly forbidden in Islam.

Also, the principles of social responsibility discussed in Kitab Al-Jidar focus on how the community should play a collective role in the neighbourhood. It includes the obligation to take care of, maintain and be responsible for any costs incurred in the restoration or repair of damaged facilities. Among the examples, Kitab Al-Jidar suggests a solution for the rehabilitation or reconstruction of a well (water source used to irrigate crops) shared by two neighbouring parties in the event of damage or collapse. According to Sahnun, the solution suggested in this book is as follows:

(a) Both parties are responsible for the repair of the well.

(b) The cost of maintenance must be shared.

(c) If one of the parties refuses to do so it must do so;

i. Repay the cost of the repairer, or;

ii. Sell his share to the party that rebuilt it.

iii. If he still refuses, the judge or qadhi shall have the right to use his power to sell the part to cover the expense spent by another party.

Kitab Al-Jidar also discussed the responsibility for the cleaning and emptying of the cesspool tank shared by the occupants of the upper and lower floors. The cost must be divided either based on the size of the house or household ratio. The cost of maintenance is born by society, and the rich would usually pay more than the poor.

\subsection{Discussion}

\subsection{Right of use of open spaces}

In the meantime, Saha is open spaces located at the y-shaped intersection of two streets in a neighbourhood, dominated by a grocery store. According to Ezzeddine \& Kashwani (2019), Saha is relatively limited in size, with access from the alleys and passageways. They were the focus of social life. Urban squares have become important venues for social activities and traditions. In big cities, the emphasis is usually on the spaces that city-dwellers join daily. This concept also applies to neighbourhoods, where there are only one or two accessible public areas in the middle of the village available to all residents. Usually, they can manage most of the group tasks that escape the need for marginal Saha (Ezzeddine \& Kashwani, 2019).

Ownership and the right to use the fina are parallel to the current use of open spaces or common facilities in neighbourhood areas. In Malaysia, for example, developers need to create essential facilities such as a playground, a public hall and a pavement in open spaces or residential areas. These open spaces are widely used today for parties, festivals and other social activities. As a result, it provides a platform for a social atmosphere, especially in urban areas where society usually lives on a hectic schedule.

The provision of adequate parks and spaces with a variety of facilities and leisure opportunities is vital to cultivating social interaction among society. Salih, Ismail \& Hamid (2018) said that sound social interaction requires an appropriate open space to meet the needs of the community in preserving an excellent neighbourly relationship between residents (Ezziti, 2018).

\subsection{Right of property}

In the current practices, all house renovations are subject to the approval of the authorities and specific guidelines laid down by the Resident Association, with the intention to avoid harm and inconvenience to the surrounding neighbours. Based on the division of the 
rights of al-irtifaq (servitude rights), it is found that some of them are still applicable in this modern practice, namely the right of way and the right of al-ta'alli. For example, through the Rukun Tetangga Act and the Strata Rights Act, people must observe and abide by these rights to prevent disputes. This elaboration does not mean that the other rights are no longer valid. Meanwhile, they have already been implemented by municipal authorities, such as irrigation systems, drainage systems and wastewater systems in residential areas. There are many pearls of wisdom behind this provision of syuf'ah, among them to avoid conflicts that may occur and to prevent harm from those who have just entered (new partners).

\subsection{Right of privacy}

It is advocated that the right to privacy, as stipulated in Islam, should be extended in the context of modern developments in housing. Residents should also respect the dignity of each other. The right to privacy should be protected and safeguarded as it generates mutual respect between society. However, the right to privacy should not be hindered by a social environment. Unfortunately, however, all these conceptions have changed in modern times. The interpretation of visual privacy expressed in Islam contradicts Western values. The West views privacy as separate from any interference while In Islam, privacy is intended to protect human dignity (Hakim, 1986; Hamza, 2010; Daneshpour, 2011).

Privacy is also useful in maintaining a peaceful and secure home. In Islam, a home is conceived as (a) a place for personal and family privacy, (b) a modest space for religious activities at home while expressing modesty in the neighbourhood, and (c) a framework for enhancing hospitality and improving relations with family and society. Hence, humankind is responsible for setting a pleasant built environment by serving as real successors or caliphs (Othman, Aird, \& Buys, 2015) (Othman, Aird, \& Buys, 2015).

\subsection{Self-built system}

Generally, public facilities in the traditional Islamic built environment have been set up under Waqf Khayri. Waqf has been described as an essential tool for the promotion of social development through individual social responsibilities towards society (Kusumaningtias \& Surabaya, 2020). Waqf carries out the activities of benevolence to include all aspects of social security and play a significant role in solving contemporary social problems (Alam \& Author, 2018).

The charitable work of self-constructed facilities is often related to the principle of collective action, or better known as 'gotongroyong' by the Malaysians. Residents can cooperate in the provision of services, maintenance, cleanliness and safety in their residential areas. Today, such a charitable concept works not only through physical exercise but also through the contribution of money and donations to the provision and maintenance of certain services, such as places of worship and the public hall.

\subsection{Responsibility for infrastructure maintenance}

In contemporary practice, the disposal of waste is generally under the obligation of the municipal government. However, there should be an individual responsibility for managing bulk trash, such as furniture and mattresses. They should manage on their own and not disposed of in the garbage disposal area controlled by the local authority. This trend manifests the tradition of philanthropy that ensures the viability of the facility. Responsibility for the upkeep of shared services, as discussed in Kitab Al-Jidar, has shown that the responsibility for the cleanliness and maintenance of neighbourhoods lies solely to the residents, not by the local authority. On the other hand, Mohd Dani (1997) claimed in his studies that residents could hire another party with payment to perform maintenance tasks as agreed by all Muslim jurists. Indeed, the administration of neighbourhood areas in Malaysia is either carried out by the local government, as some of the areas are public areas, surrendered to local authorities or in general, outsourced to third parties (hired by the management).

\subsection{Conclusion}

The above discussion in Kitab Al-Jidar provides an understanding of how Islamic values create and maintain a healthy relationship between residents in a built environment. Islamic guiding principles can develop a friendly environment that is feared to diminish in today's modern way of life. These principles must, therefore, be maintained and applied in contemporary practices for better interaction and a more pleasant atmosphere. Strengthening community participation is in conjunction with religious encouragement. The expression of the social values discussed in Kitab Al-Jidar also manifests that Islamic jurisprudence is essential to maintain social sustainability in society.

\section{Acknowledgements}

The authors highly appreciate the funding and support from the Ministry of Education (MOE), the Institute of Research Management \& Innovation (IRMI) of University Teknologi MARA (UiTM). The Fundamental Research Grant Scheme funds this research (Reference No: $600-$ IRMI/FRGS 5/3 (098/2019). 


\section{References}

Alam, M., \& Author, C. (2018). Waqf as a Tool for Rendering Social Welfare Services in the Social Entrepreneurship Context, (January), 87-98.

Al-Hathloul, Saleh. (1996). The Arab-Muslim city: Tradition, continuity and change in the physical environment. Riyadh: Dar Al Sahan.

Azila Ahmad Sarkawi \& Alias Abdullah. Ed. (2008). Urban planning; An Islamic perspectives. Kuala Lumpur: Arah Publications.

Bagaeen, Samer \& Uduku, Ola. Eds.,(2010). Gated communities: Social sustainability in contemporary and historical gated developments. London; Earthscan Publications.

Ezzeddine, I., \& Kashwani, G. (2019). Public Squares in UAE Sustainable Urbanism: Social Interaction \& Vibrant Environment, 9(2), 23-32. https://doi.org/10.5923/j.arch.20190902.01

Ezziti, B. E. (2018). Islamic Law and Neighborhood Building Principles: The Cases of Privacy and Avoidance of Harming Islamic Law and Neighborhood Building Principles : The Cases of Privacy and Avoidance of Harming, (December)

Hakim, Besim Selim. (1986). Arabic-Islamic cities; Building and planning principles. England: Routledge and Kegan, Paul.

Hossam Mahdy. (2017). Approaches to the conservation of Islamic cities: Sharjah: ICCROM-ATHAR Regional Conservation Centre in Sharjah.

Kusumaningtias, R., \& Surabaya, U. N. (2020). The Role of Waqf in Social Development, (March 2019). https://doi.org/10.18502/kss.v3i11.4018.

Mohammed, G. T., \& Mahmoud, N. (2013). The edge environment in Cairo : An approach to reading the social pattern language of the Middle Eastern built environment. International Journal of Sustainable Built Environment, 1(2), 227-246. https://doi.org/10.1016/j.ijsbe.2013.04.001

Mohd Dani Mohamad (1997). Partial translation with critical introduction; Notes and selected commentaries on Ibnu Al-Rami 's Kitab Al-l'lan Bi Ahkam Al-Bunyan. Doctor of Philosophy, International Islamic University Malaysia, Kuala Lumpur.

Mortada, Hisham. (2003). Traditional Islamic principles of built environment. London: RoutledgeCurzon.

Nahar, N., Sangi, S., Rosli, D. A. B. S. N., \& Abdullah, A. H. (2018). Impak Negatif Teknologi Moden Dalam Kehidupan Dan Perkembangan Kanak-Kanak Hingga Usia Remaja. International Journal of Islamic and Civilizational Studies, 1, 87-99.

Nooraddin, H. (2016). Al-fina', in-between spaces as an urban design concept : Making public and private places along streets in Islamic cities of the Middle East. Urban Design International, 3(1), 65-77. https://doi.org/10.1080/135753198350532

Norisma, W., Ismail, W., Arabi, F., Husini, E. M., Sakinah, F. N., \& Manaf, A. A. (2017). The establishment of Islamic dwelling principles for the Malaysian communities. Journal of the Malaysian Institute of Planners, 15(1), 261-270.

Norliza Isa. (2015). Developing a definition for Islamic built environment in Malaysia by Sieving through the interpretation of public opinion shapers. Thesis (PhD in Built Environment, Kuliyyah of Architecture and Environmental Design.

Osman, M. M., Rabe, S., \& Bachok, S. (2011). An investigation of factors influencing communities decision to reside in gated development in Kuala Lumpur and Selangor. (January). https://doi.org/10.13140/RG.2.1.3711.3048

Othman, Z., Aird, R., \& Buys, L. (2015). Privacy, modesty, hospitality, and the design of Muslim homes : A literature review. Frontiers of Architectural Research, 4(1), 12-23. https://doi.org/10.1016/j.foar.2014.12.001

Salih, S., \& Ismail, S. (2018). Determining The Factors Affecting Social Interaction in The Parks of Baghdad City, Iraq. Archnet-IJAR, 12(3), 40-52.

Salih, S. A., Ismail, S., \& Hamid, N. F. A. (2018). Lacking of Social Interaction at Open Spaces in the City of Baghdad, Iraq. KEER2018, Go Green with Emotion. 7th International Conference on Kansei Engineering \& Emotion Research 2018, 19-22 March 2018, Kuching, Malaysia, (146), 401-413.

Shaikh, S. A. (2015). Using waqf as social safety net \& funding public infrastructure. MUKTAMAR Waqf IQLIMI 2015.

Shari, A., \& Murayama, A. (2013). Changes in the traditional urban form and the social sustainability of contemporary cities : A case study of Iranian cities. 38 , $126-134$. https://doi.org/10.1016/j.habitatint.2012.05.007

Shokry, H. M. (2017). The Traditional Islamic City , As a Tool to Create Neo- Traditional Communities, (May 2009).

Spahic Omer. (2005). Al-Wasatiyyah and Islamic built environment. medinanet.org. Date retrieved; 26th May 2017.

Sudi, S., \& Taha, H. S. M. (2018). Hak-hak kejiranan menurut perspektif Al-Sunnah. (Vol. 2018, pp. 99-108). Proceeding of The International Conference on Contemporary Issues in Al-Quran \& Hadith 2018.

Zanirah Mustafa@Busu, Siti Fatimah Tasir, N. A. M. J. (2018). The concept of aurah: Islamic dressing code and personal grooming according to fiqh law. E-Academia Journal, $7(2), 10-19$.

Zeenat Begam Yusof. (2015). Islamic Guiding Principle (Shari'ah Law For Neighbourhood). In M. Rashid (Ed.) (pp. 34-41). Kuala Lumpur: IIUM Press. 